\title{
MANAJEMEN PERENCANAAN PROGRAM FESTIVAL JAZIRAH ARAB UNTUK MENGEMBANGKAN BAHASA DAN SENI ARAB
}

\author{
Al Lastu Nurul Fatim, Ahmad Faizal Amin, Tsabit Nurrahman, Zakiyah Arifa \\ Universitas Islam Negeri Maulana Malik Ibrahim Malang \\ email: allastufatim@gmail.com
}

\begin{abstract}
This study describes the model of approach, scope, and planning process of the Arabian Peninsula Festival (FJA) program to develop Arabic language and art learning. This research uses the descriptive qualitative method. The Data collection used is the method of interview, observation, and documentation. The results of this study are: first, the FJA program uses a bottom-up planning approach model, which overall program planning starts from the proposal or idea of some BSA HMJ management members and lecturers as compilers of the objectives of developing Arabic language and art learning. Second, the scope of this program includes short-term activities that are held regularly once a year and are incidental on a national scale. Third, the planning process has been carried out optimally with a preparation time of two months, then the stages of the activity procedure are clear and easily understood by the participants, namely the assistance of activity guidelines that determine the race by reflecting the development of Arabic language and arts such as speech, singing, poetry, calligraphy, debates, essays, reading news, and MQK in Arabic.
\end{abstract}

Keywords: Management; Planning; Language Learning Development.

\begin{abstract}
Abstrak
Penelitian ini mendeskripsikan model pendekatan, ruang lingkup, dan proses perencanaan program Festival Jazirah Arab (FJA) dalam mengembangkan pembelajaran bahasa dan seni Arab. Metode penelitian ini menggunakan jenis penelitian kualitatif, dengan data berupa deskriptif. Pengumpulan data yang digunakan yaitu metode wawancara, observasi, dan dokumentasi. Hasil penelitian ini adalah: pertama, program FJA menggunakan model pendekatan perencanaan bottom up, yang secara keseluruhan perencanaan program berawal dari usulan atau ide beberapa anggota pengurus HMJ BSA dan dosen sebagai penyusun tujuan pengembangan pembelajaran bahasa dan seni Arab. Kedua, ruang lingkup program ini termasuk jangka pendek yang diadakan rutin setahun sekali dan bersifat insidental dengan skala nasional. Ketiga, proses
\end{abstract}


perencanaan telah dilakukan secara optimal dengan waktu persiapan selama dua bulan, kemudian tahapan prosedur kegiatan jelas dan mudah dipahami oleh peserta yaitu adanya bantuan buku pedoman kegiatan yang menentukan lomba dengan mencerminkan pengembangan bahasa dan seni Arab seperti pidato, menyanyi, puisi, kaligrafi, debat, esai, baca berita, dan MQK berbahasa Arab.

Kata Kunci: Manajemen; Perencanaan; Pengembangan Pembelajaran Bahasa.

\section{A. Pendahuluan}

Pada umumnya, pembelajaran bahasa Arab hanya dipelajari dalam lingkungan pondok pesantren saja, sedangkan saat ini mulai dari tingkatan sekolah dasar sampai perguruan tinggi mulai banyak memfokuskan pembelajarannya pada bahasa Arab. Seperti pada Universitas Islam Negeri Maulana Malik Ibrahim Malang (UIN), terdapat jurusan bahasa Arab pada program studi sastra dan pendidikan. Pembelajaran bahasa Arab yang dimuat dalam jurusan bahasa Arab memiliki tujuan pembelajaran yang harus dicapai dengan mengembangkan keterampilan berbahasa Arab pada mahasiswa secara lisan dan tulisan.

Secara fungsional dan proporsional, pembelajaran bahasa Arab diarahkan pada penggunaan empat keterampilan berbahasa yaitu keterampilan mendengar (maharah istima'), keterampilan berbicara (maharah kalam), keterampilan membaca (maharah qiro'ah), dan keterampilan menulis (maharah kitabah). Pembelajaran bahasa Arab bukan hanya mengajarkan unsur-unsur kebahasaan dan keterampilan berbahasa saja, namun juga mengajarkan unsur budaya yang terkandung dalam proses pembelajarannya. Hal ini terjadi dikarenakan pembelajaran bahasa merupakan unsur dari kebudayaan manusia, yang mana pemerolehan kemampuan berbahasanya dilakukan melalui pembudayaan pembelajaran. ${ }^{1}$

Pembelajaran bahasa Arab formal biasanya dilakukan dalam kelas sesuai dengan materi dari unsur-unsur bahasa, keterampilan berbahasa, dan unsur budaya. Pembelajaran bahasa Arab diajarkan dengan berbagai prosedur pelaksanaan dalam pembelajaran secara keseluruhan. ${ }^{2}$ Kegiatan-kegiatan dalam proses pembelajaran, masih ada kaitannya dengan teori pembelajaran.

Ada berbagai teori pembelajaran yang dapat diimplementasikan dalam pembelajaran bahasa Arab, yaitu: a) behaviorisme, meningkatkan kemampuan bahasa dengan menerapkan prinsip pembelajaran klasikal ${ }^{3}$ b) kognitivisme, pembelajaran bahasa menjadi faktor perkembangan

\footnotetext{
${ }^{1}$ Ismail Suardi Wekke, Model Pembelajaran Bahasa Arab (Yogyakarta: Deepublish Publisher, 2012), h. 9.

${ }^{2}$ Munif Hadhir Ad-Dhowi, An-Nadzariyah Al-Bina'iyah Fi Tadris Al-Lughah AlArabiyah (Riyadh: Maktabah al-Mulk Fahdi Wathoniyah, 2013), h. 108.

${ }^{3}$ Rusman, Model-Model Pembelajaran Mengembangkan Profesionalisme Guru (Jakarta: Grafindo Persada, 2011), h. 144.
} 
memproses informasi, memecahkan masalah, menemukan konsep secara verbal dan visual yang akan disimpan dalam memori jangka panjang; ${ }^{4} \mathrm{c}$ ) konstruktivisme, memberi kesempatan peserta didik untuk memproses atau menerapkan ide-ide mereka sendiri ${ }^{5}$ d) humanistik, pendidik sebagai pendorong agar peserta didik mampu memproses informasi secara efektif. Teori pembelajaran tersebut dapat diaplikasikan pendidik dalam pembelajaran bahasa Arab secara formal atau non formal.

Teori-teori tersebut diaplikasikan bukan hanya pada pembelajaran formal saja, namun teori-teori pembelajaran di atas juga pada diaplikasikan pada pembelajaran non formal. Pembelajaran bahasa Arab non formal pada program studi bahasa Arab di UIN Malang, dengan menyelenggarakan program Festival Jazirah Arab (FJA). Program ini diselenggarakan oleh program studi Bahasa dan Sastra Arab bertujuan untuk mengembangkan pembelajaran bahasa dan seni Arab pada mahasiswa jurusan bahasa Arab di Indonesia. Pengembangan pembelajaran bahasa dan seni Arab ini, dilakukan untuk menjadikan mahasiswa-mahasiswa agar dapat meningkatkan produktivitas pembelajaran bahasa Arab dengan mengapresiasikan talentatalenta mereka, serta dapat mengetahui lebih banyak bahwa bahasa dan seni Arab merupakan akar sejarah yang memiliki unsur keindahan di dalamnya. ${ }^{6}$

Program Festival Jazirah Arab ini diadakan setiap tahunnya, tepatnya pada tahun ajaran semester ganjil. Meski program Festival Jazirah Arab diperuntukkan hanya untuk ranah nasional saja, kenyataannya terdapat universitas luar negeri dari Malaysia yang juga ikut berpartisipasi dalam program FJA ini. Dengan adanya peserta dari universitas internasional ini, menjadikan program Festival Jazirah Arab ini sudah mulai dikenal dan diminati oleh mahasiswa universitas-universitas nasional maupun internasional.

Berkembangnya suatu program FJA ini, tentunya terdapat tujuan-tujuan yang dioperasionalkan dengan berbagai kegiatan agar misi dapat tercapai. Program yang baik, yaitu program yang telah didasari oleh model teoritis secara jelas, seperti menentukan persoalan yang ingin diatasi dan dijadikan sasaran intervensi. ${ }^{7}$ Artinya, suatu program dapat dilaksanakan dan diatasi

\footnotetext{
${ }^{4}$ Baharuddin dan Esa Nur Wahyuni, Teori Belajar \& Pembelajaran (Yogyakarta: ArRuzz Media, 2007), h. 111.

${ }^{5}$ Trianto, Mendesain Model Pembelajaran Inovatif-Progresif : Konsep, Landasan dan Implementasinya pada Kurikulum Tingkat Satuan Pendidikan (Jakarta: Kencana Prenada Media Group, 2010), h. 28.

${ }^{6}$ Idham Muhammad Hans, "Al-Wihdah Wan Tanawwu' Fi Nadzriyati Al-Fan AlIslami: Unity and Diversity in the Theory of Islamic Art," Al-Fikr al-islāmī al-mu'āṣir 18, no. 69 (2012): 146-119, https://doi.org/10.35632/citj.v18i69.875.

${ }^{7}$ Ramandita Shalfiah, "Peran Pemberdayaan Dan Kesejahteraan Keluarga (PKK) Dalam Mendukung Program-Program Pemerintah Kota Bontang," Jurnal Fisipol Universitas
} 
keterhambatannya, apabila telah menentukan arah, tujuan, visi, misi, dan kegiatan apa saja, bahkan sampai pada proses evaluasi apa yang akan dilakukan. Hal ini dapat diperoleh dan dilakukan dengan adanya perencanaan sebelumnya.

Perencanaan menjadi proses dalam pengolahan suatu aktivitas organisasi, yang mana perencanaan termasuk pada fungsi manajemen. ${ }^{8}$ Sebagai fungsi manajemen, perencanaan merupakan fungsi utama manajemen yang berhubungan dengan segala sesuatu yang dikerjakan oleh manajer untuk mengatur tujuan serta bagaimana mencapai tujuan tersebut agar lebih fokus dan terarah. Hal ini didukung dengan pendapat Sa'ud yang menyatakan bahwa perencanaan termasuk rangkaian proses kegiatan menyiapkan keputusan berkaitan dengan apa yang diharapkan terjadi dan apa yang akan dilakukan. ${ }^{9}$

Sebagai fungsi utama atau fundamental sebelum melangkah pada fungsifungsi yang lainnya, perencanaan menghubungkan semua pihak dalam menentukan arah, tujuan, visi, misi, dan kegiatan apa saja, sampai dengan pada proses evaluasi apa yang akan dilakukan sebelumnya, guna mengurangi atau mengatasi jika terjadinya keterhambatan dalam pelaksanaan suatu program atau organisasi.

Adapun dalam menyusun sebuah perencanaan, terdapat empat model yang dapat dipilih dan menjadi tolak ukur keberhasilan, yaitu: a) bottom up approach, penyusunan rencana suatu kegiatan yang dimulai atau diusulkan oleh pihak yang berada pada level down (bawah) kepada pihak yang berada pada level top (atas); b) top down approach, penyusunan rencana suatu kegiatan yang dimulai dan ditetapkan oleh pihak yang berada pada level top (atas) agar dapat direalisasikan prosesnya oleh pihak pada level down (bawah); c) interactive approach, penyusunan rencana suatu kegiatan yang dilakukan bersama-sama oleh pihak yang berada pada level top dan level down; d) dual-level approach, penyusunan rencana suatu kegiatan yang dilakukan oleh masing-masing pihak pada level top atau level down yang pada akhirnya dilakukan tahap penyelarasan. ${ }^{10}$

Dalam perencanaan memiliki ruang lingkup yang dipengaruhi oleh dimensi waktu, spasial, dan tingkatan teknis perencanaan, yang mana ketiga

Mulawarman 1, no. 3 (2017): 975-84,

http://perpustakaan.unmul.ac.id/ejournal/index.php/um/article/view/92.

8 Onisimus Amtu, Manajemen Pendidikan di Era Otonomi Daerah; Konsep,

Strategi, dan Implementasi (Bandung: Alfabeta, 2011), h. 30.

${ }^{9}$ Udin Syaefudin Sa'ud dan Abin Syamsuddin Makmun, Perencanaan Pendidikan:

Suatu Pendekatan Komprehensif (Bandung: Remaja Rosdakarya, 2014), h. 3-4.

${ }^{10}$ Sugiyanto, Dasar-Dasar Manajemen Kristiani (Jakarta: Gunung Mulia, 2008), h.

31. 
dimensi tersebut saling berinteraksi satu sama lain. ${ }^{11}$ Ketiga ruang lingkup perencanaan terbagi menjadi beberapa bagian, seperti:

1. Dimensi waktu terbagi menjadi tiga bagian; a) perencanaan jangka pendek (minimal 1 tahun); b) perencanaan jangka menengah (1-4 tahun); c) perencanaan jangka panjang (4-8 tahun).

2. Dimensi spasial, perencanaan yang memiliki karakter berkaitan dengan ruang dan batasan wilayah, terbagi menjadi; a) perencanaan nasional; b) perencanaan regional; c) perencanaan tata ruang.

3. Dimensi tingkatan teknis perencanaan terbagi menjadi lima bagian; a) perencanaan makro; b) perencanaan mikro; c) perencanaan sektoral; d) perencanaan kawasan; perencanaan proyek.

Sebagaimana kita ketahui, agar tujuan kegiatan dapat tercapai dibutuhkan perencanaan yang tersusun dengan baik dan dijalankan melalui tahapan proses secara sistematis. Tahapan dalam menjalankan proses perencanaan, sebagai berikut: a) melakukan prakiraan; b) menetapkan tujuan; c) menyusun program; d) melakukan penjadwalan; e) menyusun anggaran; f) mengembangkan prosedur; g) menetapkan interpretasi kebijakan. Dengan dilakukannya program sesuai dengan aspek perencanaan yang ada, maka dapat dipastikan pengembangan pembelajaran bahasa dan seni Arab dapat dicapai dengan baik sesuai tujuan. ${ }^{12}$

Pemaparan sebelumnya didukung oleh beberapa penelitian yang membahas tentang pengembangan pembelajaran bahasa Arab dengan pemfokusan yang berbeda-beda, seperti: peneliti pertama, memfokuskan penelitiannya pada pelaksanaan program bahasa Arab, faktor pendukung pelaksanaan program bahasa Arab, dan kemampuan keterampilan berbahasa Arab. ${ }^{13}$ Peneliti kedua, memfokuskan penelitiannya pada konsep kekeluargaan dan profesionalisme, program kerja mahasiswa, dan partisipasi mahasiswa dalam organisasi mahasiswa Sastra Arab. ${ }^{14}$ Penelitian ketiga, memfokuskan penelitiannya pada pengawasan dan evaluasi pembelajaran bahasa Arab pada program khusus pengembangan bahasa Arab (PKPBA). ${ }^{15}$

${ }^{11}$ Husaini Usman, Manajemen: Teori, Praktik, Dan Riset Pendidikan (Jakarta: Bumi Aksara, 2008), h. 81-85.

${ }^{12}$ Siswanto, Pengantar Manajemen (Jakarta: Bumi Aksara, 2010), h. 45-47.

${ }^{13}$ Ulfah Fauziyah Rahmah, "Program Pembelajaran Bahasa Arab Di SMP Plus AlAqsha Jatinagor Sumedang," An Nabighoh: Jurnal Pendidikan Dan Pembelajaran Bahasa Arab 21, no. 02 (2019): 255, https://doi.org/10.32332/an-nabighoh.v21i02.1680.

${ }^{14}$ Faisal Hendra, "Peran Organisasi Mahasiswa dalam Meningkatkan Mutu Pembelajaran Keterampilan Berbahasa Arab," Arabiyat : Jurnal Pendidikan Bahasa Arab dan Kebahasaaraban 5, no. 1 (2018): 103-20, https://doi.org/10.15408/a.v5i1.7480.

${ }^{15}$ Thia Razimona, “Pengawasan dan Evaluasi Program Bahasa Arab untuk Peningkatan Berkelanjutan di Universitas Islam Negeri Maulana Malik Ibrahim, Malang," Al- 
Berdasarkan pemaparan di atas, peneliti akan memfokuskan penelitiannya pada: 1) bagaimana model pendekatan perencanaan; 2) bagaimana ruang lingkup perencanaan; 3) bagaimana proses perencanaan program Festival Jazirah Arab dalam mengembangkan pembelajaran bahasa dan seni Arab. Pembahasan ini menunjukkan bagaimana jalannya program Festival Jazirah Arab dalam melakukan perencanaan, agar tujuan untuk mengembangkan pembelajaran bahasa Arab dapat tercapai dengan baik.

\section{B. Metode Penelitian}

Dalam suatu penelitian, terdapat bagian penting yang tidak bisa dihindari yaitu metode penelitian. Metode penelitian yang akan diuraikan pada penelitian ini adalah, jenis penelitian, sumber data, teknik pengumpulan data, validasi data, dan teknik analisis data.

\section{Jenis Penelitian}

Penelitian ini menggunakan jenis penelitian kualitatif, yang mana datanya menghasilkan data deskriptif berupa kata-kata tertulis maupun lisan yang dipaparkan secara rinci dari perilaku orang-orang yang diamati. ${ }^{16}$ Penelitian kualitatif ini, akan mendeskripsikan model pendekatan perencanaan program Festival Jazirah Arab. Adapun data primer bersumber pada hasil wawancara kepada pengurus Himpunan Mahasiswa Jurusan Bahasa dan Sastra Arab (HMJ BSA), panitia FJA, dan buku panduan FJA. Sedangkan data sekunder bersumber pada hasil observasi dan wawancara kepada peserta FJA dan ketua jurusan BSA.

\section{Teknik Pengumpulan Data}

Teknik pengumpulan data yang digunakan penelitian dalam penelitian ini adalah menggunakan metode wawancara, observasi, dan dokumentasi. Dalam metode wawancara, peneliti melakukan wawancara kepada: a) dosen jurusan Bahasa dan Sastra Arab, dengan mengajukan pertanyaan terkait tujuan diadakan program FJA dalam mengembangkan pembelajaran bahasa Arab; b) pengurus HMJ BSA selaku penanggung jawab program FJA, yang mana wawancara tersebut diajukan berupa pertanyaan dari peneliti seputar sejarah, tujuan, sasaran, dan bagaimana pengurus HMJ BSA mengemas seluruhnya menjadi program FJA ini; c) panitia FJA, peneliti mengajukan pertanyaan seputar bagaimana dan apa persiapan yang dilakukan panitia sebelum program ini berlangsung; d) peserta FJA, peneliti mengajukan pertanyaan seputar apa saja kekurangan

\footnotetext{
Ma'rifah: Jurnal Budaya, Bahasa, dan Sastra Arab 16, no. 2 (2019): 1-15, http://journal.unj.ac.id/unj/index.php/jba/article/view/9471.

${ }^{16}$ Kaid Abdul al-Haq Abidat Dzuqon dan Abdurrahman, Al-Bahts Al-IImi, Mafhumuhu, Adawatuhu, Asalibihi (Riyadh: Dar Isamah li an-Nashr wa at-Tauzi', 1997), h. 215.
} 
dan kelebihan dari program FJA, guna mensinkronisasikan rencana ataupun tujuan, apakah seluruh seluruhnya telah tercapai atau belum. Kemudian peneliti melakukan observasi, di metode ini peneliti melakukan observasi langsung dengan meninjau dan mengamati kegiatan-kegiatan yang dilakukan panitia maupun peserta program FJA seputar model pendekatan perencanaan yang digunakan. Selanjutnya metode terakhir yang digunakan peneliti adalah dokumentasi, yang mana pada tahap ini peneliti menggunakan dokumentasi berupa buku panduan lomba yang dapat diakses langsung dari situs web resmi FJA.

\section{Validasi Data}

Validasi data yang digunakan peneliti pada penelitian ini memiliki tiga langkah utama menurut Alwasilah ${ }^{17}$, yaitu: pertama, peneliti melakukan wawancara kepada dosen BSA, pengurus HMJ BSA, dan panitia FJA, serta observasi dengan meninjau dan mengamati kegiatankegiatan program FJA secara berulang-ulang guna mendapatkan data yang lebih banyak, serta pencatatan data dari hasil wawancara dan hasil pengamatan dari observasi agar tidak adanya data yang hilang atau terlewat; kedua, peneliti melakukan pemeriksaan ulang dari efek bias terhadap data yang telah didapat; ketiga, peneliti melakukan triangulasi guna memeriksa ulang keabsahan data yang didapat, kemudian membandingkannya dengan hasil analisis yang terjadi pada program FJA.

\section{Teknik Analisis Data}

Teknik analisis data dalam penelitian ini menggunakan teori Miles dan Huberman ${ }^{18}$, yang mana memiliki langkah-langkah teknik analisis data sebagai berikut: pertama, pengumpulan data dari data yang didapat peneliti melalui wawancara pengurus HMJ BSA dan panitia FJA, observasi dengan meninjau serta mengamati kegiatan-kegiatan FJA, dan dokumentasi yang didapat dari buku panduan program FJA; kedua, reduksi data yang dilakukan peneliti untuk memilah serta memilih hasil data dari wawancara, observasi, dan dokumentasi yang diperlukan, kemudian selanjutnya akan diklasifikasikan; ketiga, display data yang akan dilakukan peneliti dengan cara mengolah data yang sudah diklasifikasikan berdasarkan pola hubungan program FJA dengan model pendekatan perencanaan, kemudian data tersebut dikaji kembali kelengkapannya dari semua aspek; keempat, kesimpulan diambil peneliti dari hasil penyajian data.

\footnotetext{
${ }^{17}$ Chaedar Alwasilah, Pokoknya Kualitatif (Jakarta: Pustaka Jaya, 2008), h. 53.

${ }^{18}$ Matthew B. Miles, A. Michel Huberman, dan Johnny Saladana, Qualitative Data Analysis A Methods Sourcebook Edition 3 (New York: SAGE Publications, 2014), 22.
} 


\section{Hasil dan Pembahasan}

Pembahasan manajemen perencanaan program FJA telah dilakukan peneliti sesuai dengan pemfokusan penelitian ini. Hasil penelitian yang diperoleh peneliti di lapangan, berdasarkan dari hasil observasi, wawancara, dan dokumentasi. Peneliti akan memaparkan hasil penelitian beserta diskusinya, sebagai berikut:

\section{Model Pendekatan Perencanaan FJA}

Program ini terbentuk dengan adanya persetujuan dari semua pihak, pembahasan mengenai desain acara pada program FJA tidak jauh berbeda dengan alur pembentukan FJA itu sendiri. Desain acara yang ada di program FJA pertama-tama dibuat dan disusun oleh pengurus HMJ BSA serta panitia FJA, kemudian hasil dari kesepakatan dalam prosedur dan susunan acara pada program FJA dikoordinasikan kepada ketua fakultas Humaniora dan ketua jurusan BSA, sehingga acara pada program FJA ini dapat berjalan dengan baik dan sesuai prosedur yang ada, serta dapat dipertanggung jawabkan oleh semua pihak yang bersangkutan. ${ }^{19}$

Proses perencanaan yang dilakukan oleh panitia FJA merupakan tahapan pertama, sebagaimana yang diungkap Sugiyanto bahwa dalam menyusun sebuah perencanaan, terdapat model pendekatan yang menjadi tolak ukur keberhasilan menjalankan proses perencanaan. Dalam program ini model yang dipakai adalah Bottom up approach, yang mana penyusunan rencana suatu kegiatan atau program yang dimulai atau diusulkan oleh pihak yang berada pada level down (bawah) kepada pihak yang berada pada level top (atas). ${ }^{20}$

Pendekatan ini memiliki dua perspektif ${ }^{21}$ : pertama, melibatkan pihak setempat (dalam hal ini mahasiswa) dalam pemilihan, perancangan dan pelaksanaan program sesuai dengan persepsi setempat, pola sikap, pola pikir serta pengetahuan yang dipertimbangkan secara matang. Kedua, membuat feedback terhadap program yang dilaksanakan, dalam artian mahasiswa sebagai pelaksana kegiatan mengetahui betul bagaimana proses kegiatan sehingga dapat menentukan hal-hal yang berdampak baik terhadap kegiatan tersebut. Bottom up digunakan sebagai pendekatan perencanaan program FJA karena program tersebut merupakan program yang dibentuk oleh pengurus HMJ BSA (down) yang kemudian diusulkan kepada Ketua Jurusan BSA dan Fakultas Humaniora (top) untuk

\footnotetext{
${ }^{19}$ Hasil wawancara dengan Andika Putra Adi Prasetyo selaku Ketua HMJ BSA (Malang, 7 November 2018).

${ }^{20}$ Sugiyanto, Dasar-Dasar Manajemen Kristiani, h. 31.

${ }^{21}$ Riedel Legi, Wilson Y. Rompas, dan Jericho D. Pombengi, "Implementasi Pendekatan Bottom Up Dalam Perencanaan Pembangunan Desa Di Kecamatan Tumpaan Kabupaten Minahasa Selatan," Jurnal Administrasi Publik 1, no. 010 (2015), https://ejournal.unsrat.ac.id/index.php/JAP/article/view/6537.
} 
dikoordinasikan agar sesuai prosedur yang ada di fakultas dan jurusan UIN Maulana Malik Ibrahim Malang. Secara konseptual, semua desain program ini juga menggunakan pendekatan bottom up, dimulai dari kerangka acara yang dibuat Panitia FJA kemudian dikoordinasikan kepada pengurus HMJ BSA dan disetujui oleh Ketua Jurusan BSA.

Meski secara teknis jalannya program FJA menggunakan pendekatan bottom up, namun tetap saja para pendidik atau dosen juga menjadi penyusun tujuan utama kegiatan program FJA agar benar-benar dapat mengembangkan pembelajaran bahasa dan seni Arab. Pencapaian tujuan dalam unsur kebahasaan, keterampilan berbahasa, dan unsur kebudayaan guna mengembangkan pembelajaran bahasa dan seni Arab, para dosen menyusun kegiatan program FJA dengan mengaplikasikan teori pembelajaran bahasa.

\section{Ruang Lingkup Perencanaan FJA}

Program FJA dilaksanakan setahun sekali yang berskala nasional, dalam artian pesertanya adalah mahasiswa Perguruan Tinggi (PTN/PTS/PTAIN/PTAIS) pecinta bahasa Arab seluruh Indonesia, namun pada tahun ini terdapat peserta dari luar negeri yaitu Universitas Sains Islam Malaysia. Perencanaan program ini bersifat program khusus insidental yang dicanangkan oleh keanggotaan khusus serta terbatas, dalam artian program ini merupakan salah satu program kerja yang dimiliki HMJ BSA yang kemudian dijalankan secara khusus oleh mahasiswa BSA semester 3 dan 5.

Perencanaan program FJA dipengaruhi oleh tiga dimensi yang saling berinteraksi, maka program FJA dalam dimensi waktu tergolong dalam perencanaan jangka pendek karena program ini merupakan program yang diadakan setahun sekali. Sedangkan dalam dimensi spasial tergolong dalam perencanaan nasional karena program ini berskala nasional dalam artian pesertanya adalah mahasiswa Perguruan Tinggi (PTN/ PTS/ PTAIN/ PTAIS) pencinta bahasa Arab seluruh Indonesia. Kemudian dalam dimensi tingkatan teknis perencanaan tergolong perencanaan proyek karena perencanaan ini bersifat program khusus bersifat insidental dan memiliki jangka waktu lebih sempit dan dicanangkan oleh keanggotaan khusus dan terbatas.

Dengan ini, perencanaan program FJA sudah sesuai dengan apa yang dikatakan Usman bahwa dalam sebuah perencanaan harus terdiri dari tiga dimensi yang saling berkaitan. ${ }^{22}$ Dalam hal ini dimensi waktu merupakan sebuah acuan waktu sebuah program atau kegiatan yang akan dilaksanakan, kemudian dimensi spasial merupakan sebuah acuan skala

\footnotetext{
${ }^{22}$ Usman, Manajemen: Teori, Praktik, Dan Riset Pendidikan, h. 81.
} 
peserta yang akan berpartisipasi dan dimensi tingkatan teknis perencanaan merupakan identifikasi bentuk dari sebuah program.

\section{Proses Perencanaan FJA}

Proses perencanaan FJA dapat dijalankan dengan baik, apabila tujuan dari suatu kegiatan telah disusun secara sistematis. Adapun tahapan dalam menjalankan suatu proses perencanaan adalah sebagai berikut:

a) Prakiraan

Terbentuknya program Festival Jazirah Arab tidak lepas dari prakiraan atau perhitungan secara rasional dalam sejarah Jazirah Arab itu sendiri. Sejarah Jazirah Arab dengan sastra, bahasa, dan peradaban keemasan dalam berbagai keilmuan, yang selalu menjadi sorotan utama dalam perkembangan bangsa Arab, menjadikan acuan untuk dapat mengapresiasikan bahasa dan kesenian Arab, yang akan ditunjukkan melalui talenta-talenta mahasiswa jurusan bahasa Arab di Indonesia, guna membantu mereka dalam mengembangkan pembelajaran bahasa Arab dari unsur-unsur kebahasaan, keterampilan berbahasa, dan unsur kebudayaan.

Program FJA ini diselenggarakan oleh Himpunan Mahasiswa Jurusan Bahasa dan Sastra Arab (HMJ BSA) UIN Maulana Malik Ibrahim Malang, yang mana program ini selalu diadakan setiap tahunnya pada tahun ajaran semester ganjil, yang mana program ini juga diadakan selama seminggu. Dalam seminggu, program ini menyajikan beberapa kegiatan, seperti lomba-lomba dalam seni sastra, seminar nasional, bazar buku, dan malam apresiasi. Program FJA ini juga memiliki tema "Keistimewaan Sastra, Taburkan Seni Bahasa dalam Kehangatan Jazirah Arab".

b) Penetapan Tujuan

Seperti yang telah dipaparkan sebelumnya, bahwa program Festival Jazirah Arab ini telah memiliki prakiraan, artinya program ini pula juga telah menentukan tujuan dalam penyelenggaraannya. Tujuan secara umum dari program FJA adalah, untuk mengapresiasikan dan mengembangkan kesenian-kesenian Arab, yang mana pengapresasian tersebut ditunjukkan melalui talenta-talenta yang dimiliki oleh mahasiswa-mahasiswa jurusan bahasa Arab khususnya. ${ }^{23}$ Adapun tujuan kegiatan program FJA dalam mengembangkan pembelajaran bahasa dan seni Arab:

1) Lomba menyanyi memiliki tujuan: (a) melatih mahasiswa untuk terbiasa mengucapkan bahasa Arab sesuai dengan dialek Arab; (b) mempraktekkan secara langsung pada mahasiswa dalam melafalkan

${ }^{23}$ Hasil Wawancara dengan Andika Putra Adi Prasetyo selaku Ketua HMJ BSA (Malang, 8 November 2018). 
fonem bahasa Arab dengan benar; (c) melatih kejelasan pelafalan berbahasa Arab dalam bentuk lagu; (d) membantu memahami makna dari lagu-lagu Arab; (e) melatih tingkatan penerjemahan mahasiswa dalam menerjemahkan lagu berbahasa ibu ke bahasa Arab, sesuai dengan qowa'id yang benar; (f) mengenalkan keindahan makna dari seni Arab dalam bentuk lagu.

2) Esai berbahasa Arab memiliki tujuan: (a) membiasakan mahasiswa dalam merangkai kosakata bahasa Arab yang telah mereka dapat sesuai dengan qowa'id; (b) melatih mahasiswa untuk cermat dalam setiap rangkaian kosakata bahasa Arab sesuai dengan tema yang ditentukan; (c) mengembangkan wawasan atau pengetahuan mahasiswa yang dituangkan dalam bentuk tulisan; (d) melatih mahasiswa dalam pengungkapan makna pada struktur bahasa sesuai dengan maksud yang akan diutarakan dalam bentuk tulisan.

3) Lomba debat memiliki tujuan: (a) melatih mahasiswa dalam pelafalan kalimat bahasa Arab secara langsung sesuai dengan artikulasi yang benar; (b) melatih mahasiswa untuk dapat mengungkapkan ide atau pengetahuan yang mereka kembangkan sendiri sesuai tema dalam bentuk tulisan, yang nantinya akan mereka kembangkan kembali secara lisan; (c) bertanggung jawab penuh atas ide atau argumen yang dikembangkan sendiri, agar dapat tersampaikan secara tepat; (d) melafalkan ide atau argumen dengan berbahasa Arab sesuai dengan susunan kaidah bahasa; (e) membantu memahami makna bahasa Arab dari ide atau argumen lawan debat secara cepat dan tepat.

4) Membaca berita memiliki tujuan: (a) membantu mengenalkan naskah berbahasa Arab, sebelum membacakan berita terkini; (b) menggunakan kosakata yang sesuai dengan makna bahasa Arab dalam teks berita; (c) melatih untuk dapat berbicara bahasa Arab sesuai fonem yang benar.

5) MQK memiliki tujuan: (a) mengenalkan naskah-naskah kuno bahasa Arab dengan baik; (b) memahami makna bahasa Arab dengan baik pada naskah sesuai dengan tema; (c) memahami kaitan makna dari satu kalimat ke kalimat yang lainnya; (d) memahami kaidah bahasa Arab yang terdapat pada naskah kuno tersebut.

6) Kaligrafi memiliki tujuan: (a) mengenalkan keindahan seni Arab dalam bentuk tulisan; (b) melatih berbagai macam bentuk seni tulisan Arab, yang kemudian diperindah dan dikembangkan sendiri oleh mahasiswa.

7) Pidato memiliki tujuan: (a) membiasakan mahasiswa dalam merangkai kosakata bahasa Arab yang telah mereka dapat sesuai dengan qowa'id; (b) melatih untuk dapat merangkai tulisan 
berbahasa Arab sesuai dengan tema, dan kemudian dikembangkan dengan berbagai pendapat atau ide; (c) melatih mahasiswa untuk dapat mengekspresikan tulisannya secara lisan dengan tepat; (d) melatih kefasihan dalam melafalkan kalimat secara lisan.

Dengan adanya penetapan tujuan, maka dapat membantu program FJA ini untuk menentukan aktivitas sesuai dengan tujuan yang telah direncanakan sebelumnya. Tujuan program FJA ini masih bersifat umum dan dalam pengembangan pembelajaran bahasa Arab ini akan diuraikan aktivitas dari tujuan pada paparan pemrograman.

c) Pemrograman

Tahap ini merupakan tahapan dengan aktivitas yang disesuaikan dengan tujuan dalam program yang akan dilaksanakan. Pemrograman Festival Jazirah Arab periode 2018 ini telah merumuskan, pertama target yang dapat diinterpretasikan pada tujuan khusus dari pelaksanaan program ini, yaitu: 1) mengembangkan pembelajaran bahasa dan seni Arab dalam bentuk lomba, guna mengapresiasikan talenta-talenta mahasiswa jurusan bahasa Arab; 2) menyatukan dan mengembangkan minat dan bakat mahasiswa dalam bahasa Arab yang dapat diikuti seluruh mahasiswa jurusan bahasa Arab maupun mahasiswa jurusan lainnya; 2) mempererat ukhuwah islamiyah, yang mana terjalinlah ikatan antara mahasiswa jurusan bahasa Arab di seluruh Indonesia, dengan ini maka dapat mencetak generasi berkualitas dan matang dalam bahasa Arab; 3) pada umumnya ingin memperkenalkan proses pembelajaran bahasa Arab di UIN Maulana Malik Ibrahim Malang, serta jurusan Bahasa dan Sastra Arab pada khususnya kepada seluruh peserta.

Kedua, sasaran yang mana FJA telah mensegmentasikan peserta yang akan mengikuti program ini. Sasaran yang ditujukan bersifat Nasional, artinya dapat diapresiasikan oleh mahasiswa Universitas Islam Negeri Maulana Malik Ibrahim Malang, mahasiswa perguruan tinggi se-Malang raya, mahasiswa perguruan tinggi (PTN/ PTS/ PTAIN/ PTAIS) pencinta bahasa Arab seluruh Indonesia, serta masyarakat umum pencinta bahasa Arab.

Ketiga, kerangka konseptual acara FJA dimaksudkan untuk mengembangkan pembelajaran bahasa Arab berupa: 1) lomba-lomba tingkat nasional yang terbagi sesuai kategorinya masing-masing. Untuk lomba kategori mahasiswa, terdiri dari lomba debat berbahasa Arab, menyanyi berbahasa Arab, puisi berbahasa Arab, esai berbahasa Arab, dan baca berita berbahasa Arab. Sedangkan untuk lomba dengan kategori umum, terdiri dari kaligrafi, pidato bahasa Arab, dan mushabaqoh qiroatul kutub (MQK); 2) bazar buku, kegiatan ini 
dilakukan dari awal dimulainya acara sampai selesainya acara, yang mana pada bazar buku ini menjadi sarana bagi peserta untuk semakin memperkaya wawasan mengenai kajian-kajian yang terkait dengan pembelajaran bahasa dan sastra Arab; 3) seminar nasional, merupakan upaya untuk mengembangkan dan meningkatkan semangat dalam berkarya seni secara optimal, dengan menghadirkan KH. Ahmad Mustofa Bisri sebagai pemateri; 4) malam apresiasi, merupakan rangkaian acara puncak apresiasi karya sastra dan penutupan kegiatan Festival Jazirah Arab.

d) Penjadwalan

Penjadwalan merupakan tahapan yang telah menetapkan atau menentukan waktu kegiatan program Festival Jazirah Arab 2018 berlangsung, adapun pemaparan jadwal kegiatan yang dilakukan selama seminggu, sebagai berikut: 1) pada hari Sabtu tanggal 3 November pukul 06.00, panitia melakukan penjemputan peserta di terminal maupun stasiun kota; 2) Minggu tanggal 4 November pukul 07.00 terdapat acara registrasi peserta dan technical meeting lomba; 3) Senin tanggal 5 November pukul 07.30 terdapat pembukaan FJA; 4) Selasa tanggal 6 November pukul 08.00, terdapat jadwal perlombaan kaligrafi dan pidato bahasa Arab; 5) Rabu tanggal 7 November pukul 08.00, terdapat jadwal perlombaan menyanyi dan esai berbahasa Arab, serta seminar nasional dengan tema "Estetika Bahasa dan Sastra Wujudkan Perdamaian Nusantara"; 6) Kamis tanggal 8 November pukul 08.00, terdapat perlombaan debat, membaca berita berbahasa Arab, dan MQK; 7) Jumat tanggal 9 November pukul 08.00, terdapat acara semi final lomba debat berbahasa Arab; 8) Sabtu tanggal 10 November pukul 19.00, terdapat acara malam apresiasi dan penutupan FJA. Adapun keseluruhan jadwal di atas telah tertera pada rundown acara di buku panduan FJA. ${ }^{24}$

e) Penganggaran

Suatu program dapat berjalan lancar, apabila dalam proses perencanaannya juga menetapkan anggaran, dan dari mana asal sumber dana telah terpatok dengan baik, serta tersusun secara sistematis alur pembelanjaannya. Festival Jazirah Arab merupakan program tahunan rutin, yang mana program ini dari awal sebelum proses kegiatan berlangsung telah menetapkan anggaran, sehingga dapat menunjang keberlangsungan program dari segi materiil. Adapun sumber dana yang didapat berasal dari tiga unsur utama, yaitu dari pihak fakultas,

${ }^{24}$ Panitia FJA 2018, "Buku Panduan Festival Jazirah Arab 2018” (HMJ BSA UIN Maulana Malik Ibrahim Malang, 2018), h. 12-30, http://festivaljaziraharab.blogspot.com/p/blog-page_44.html. 
administrasi dari pendaftaran peserta lomba, dan keterlibatan sponsor. ${ }^{25}$

f) Pengembangan Prosedur

Dalam setiap program tentunya telah ditetapkan prosedur mana yang akan ditempuh, agar rangkaian kegiatan dapat berjalan secara sistematis, dengan tidak menyalahi kebijakan atau aturan yang telah berlaku, di mana suatu kegiatan berlangsung.

Festival Jazirah Arab mengembangkan prosedur terarah melalui instruksi dari atas ke bawah berdasarkan pola struktural, yaitu dengan adanya steering committee (SC) menjadi peletak konsep dasar utama berjalannya kegiatan, yang kemudian direspons dengan baik oleh pihak jurusan bahasa dan sastra Arab sebagai penanggung jawab. Kemudian konsep kegiatan pada program tersebut disalurkan secara prosedur melalui tim pelaksana atau committee organizing (CO), kemudian ketua pelaksana melakukan koordinasi kepada anggota pelaksana lainnya. Adapun tahap awal pelaksanaan dimulai dari penyebaran surat ke setiap instansi, serta penyebaran proposal ke setiap sumber dana yang telah ditetapkan sebelumnya.

g) Penetapan dan Interpretasi Kebijakan

Dalam menjalankan suatu program, harus ada format kebijakan yang dapat menjamin keberlangsungan program tersebut. Festival Jazirah Arab dipandang sebagai program yang sah, legal, dan terarah, karena peran sumber daya di dalamnya telah dipegang secara tanggung jawab dalam menentukan atau menjalankan kebijakan, untuk menjamin berlangsungnya program ini secara aman, dan tujuan yang telah ditargetkan dapat tercapai. Dengan adanya format surat keputusan program FJA, membuktikan bahwa program ini telah diatur dengan baik, secara prosedur, dana arah komando yang dapat terkontrol dengan baik.

Proses perencanaan telah dilakukan sesuai dengan tahapannya, artinya perencanaan program FJA telah berjalan sesuai dengan tujuan. Seperti yang diketahui bahwa perencanaan yang baik merupakan perencanaan yang memiliki prinsip yang tertera dalam dokumen perencanaan tentang apa yang harus dilaksanakan berdasarkan penjabaran visi dan misi; bagaimana mencapainya; siapa yang akan melaksanakannya; bagaimana lokasi serta waktu yang dibutuhkan; dan

${ }^{25}$ Hasil Wawancara dengan Andika Putra Adi Prasetyo selaku Ketua HMJ BSA (Malang, 9 November 2018). 
bagaimana sumber daya yang dibutuhkan. ${ }^{26}$ Selaras dengan apa yang dikatakan Siswanto bahwa tujuan kegiatan bisa tercapai dengan baik apabila proses perencanaannya disusun secara sistematis yang terdiri dari prakiraan; penetapan tujuan; pemrograman; penjadwalan; penganggaran; pengembangan prosedur; penetapan dan interpretasi kebijakan. ${ }^{27}$

Untuk mengetahui tingkat keberhasilan sebuah perencanaan dengan tujuan yang sudah ditetapkan, maka Menurut Goldblatt dari sekian banyak proses perencanaan dibagi menjadi tiga fokus yaitu timing, space, dan tempo. Timing adalah bagaimana kepanitiaan mengatur waktu yang tersisa untuk mempersiapkan acara, space adalah bagaimana pemilihan tempat acara, dan tempo adalah bagaimana kepanitiaan mengatur acara agar peserta yang hadir merasa nyaman. ${ }^{28}$

Secara timing, berdasarkan program FJA yang berskala nasional, terdapat rentan dua bulan yang dipersiapkan kepanitiaan untuk mempersiapkan acara sesuai dengan tujuan yang ingin dicapai. Dari sisi space, terdapat beberapa hal yang dipertimbangkan oleh kepanitiaan, diantaranya adalah setiap jenis lomba mempunyai kebutuhan yang berbeda-beda dan hal inilah yang menjadi patokan tempat mana yang sesuai dengan kebutuhan tiap jenis lomba. Kemudian dari segi tempo, peserta yang berpartisipasi sudah disiapkan proposal kegiatan serta buku pedoman kegiatan yang mana hal ini akan mempermudah mereka untuk mengikuti semua prosedur kegiatan.

\section{Kesimpulan}

Berdasarkan hasil penelitian dan pembahasan di atas, maka dapat disimpulkan sebagai berikut: pertama, model pendekatan perencanaan yang digunakan dalam festival jazirah Arab adalah pendekatan bottom up, yang secara keseluruhan perencanaan program berawal dari usulan atau ide dari beberapa anggota pengurus HMJ BSA dan dosen BSA sebagai penyusun tujuan pengembangan pembelajaran bahasa dan seni Arab. Kedua, festival jazirah Arab tergolong dalam program jangka pendek yang diadakan rutin setahun sekali dan bersifat program insidental serta berskala nasional. Ketiga, festival jazirah Arab dari segi proses perencanaan telah dilakukan secara optimal dan telah sesuai standar baik dari segi prakiraan, penetapan

${ }^{26}$ Enos Paselle, "Perencanaan Pembangunan Partisipatif: Studi Tentang Efektivitas Musrenbang Kec. Muara Badak Kab.Kutai Kartanegara," Jurnal Paradigma (JP) 2, no. 1 (2017): 10-25, http://e-journals.unmul.ac.id/index.php/JParadigma/article/view/339.

27 Siswanto, Pengantar Manajemen, h. 45-47.

${ }^{28}$ Fatma Nurshuma Shalawat Azh-zahra, Feliza Zubair, dan Heru Ryanto Budiana, "Perencanaan Special Event 'Pengajian Akbar Februari' oleh Hlijabers Community Bandung," Jurnal Komunikasi 11, no. 1 (2017): 1-10, https://journal.trunojoyo.ac.id/komunikasi/article/view/3017. 
tujuan, pemrograman, penjadwalan, penetapan anggaran, pengembangan prosedur dan interpretasi kebijakan. Adapun pada tingkat keberhasilan perencanaan festival jazirah Arab dari segi timing, space dan tempo telah dicapai secara optimal, hal ini dikarenakan waktu persiapan memadai yaitu selama dua bulan dengan berbagai kegiatan yang mencerminkan upaya pengembangan bahasa dan seni Arab seperti pidato berbahasa Arab, menyanyi berbahasa Arab, puisi bahasa Arab, kaligrafi dengan tulisan Arab, debat berbahasa Arab, esai Arab, membaca berita Arab, serta MQK (musabaqoh qiro'atul kutub). Adapun rekomendasi berdasarkan penelitian ini adalah; pertama, kepada peneliti selanjutnya untuk dapat menggali lebih dalam dari fungsi manajemen yang lain. Kedua, bagi kepanitiaan yang hendak menyelenggarakan program, baiknya dalam proses perencanaan harus dilakukan secara sistematis dan sesuai dengan prosedur perencanaan, agar tujuan yang diharapkan dapat tercapai dengan baik. 


\section{Daftar Pustaka}

Ad-Dhowi, Munif Hadhir. An-Nadzariyah Al-Bina'iyah Fi Tadris Al-Lughah Al-

Arabiyah. Riyadh: Maktabah al-Mulk Fahdi Wathoniyah, 2013.

Alwasilah, Chaedar. Pokoknya Kualitatif. Jakarta: Pustaka Jaya, 2008.

Amtu, Onisimus. Manajemen Pendidikan di Era Otonomi Daerah; Konsep, Strategi, dan Implementasi. Bandung: Alfabeta, 2011.

Andika Putra Adi Prasetyo. Hasil Wawancara dengan Ketua HMJ BSA, 7 November 2018.

Azh-zahra, Fatma Nurshuma Shalawat, Feliza Zubair, dan Heru Ryanto Budiana.

"Perencanaan Special Event 'Pengajian Akbar Februari' oleh Hlijabers

Community Bandung." Jurnal Komunikasi 11, no. 1 (2017): 1-10.

https://journal.trunojoyo.ac.id/komunikasi/article/view/3017.

Baharuddin, dan Esa Nur Wahyuni. Teori Belajar \& Pembelajaran. Yogyakarta: Ar-

Ruzz Media, 2007.

Dzuqon, Kaid Abdul al-Haq Abidat, dan Abdurrahman. Al-Bahts Al-IImi,

Mafhumuhu, Adawatuhu, Asalibihi. Riyadh: Dar Isamah li an-Nashr wa at-

Tauzi', 1997.

Hans, Idham Muhammad. “Al-Wihdah Wan Tanawwu' Fi Nadzriyati Al-Fan Al-

Islami: Unity and Diversity in the Theory of Islamic Art." Al-Fikr al-islāmī al-

mu'āșir 18, no. 69 (2012): 146-119.

https://doi.org/10.35632/citj.v18i69.875.

Hendra, Faisal. "Peran Organisasi Mahasiswa dalam Meningkatkan Mutu

Pembelajaran Keterampilan Berbahasa Arab." Arabiyat : Jurnal Pendidikan

Bahasa Arab dan Kebahasaaraban 5, no. 1 (2018): 103-20.

https://doi.org/10.15408/a.v5i1.7480.

Legi, Riedel, Wilson Y. Rompas, dan Jericho D. Pombengi. “Implementasi

Pendekatan Bottom Up Dalam Perencanaan Pembangunan Desa Di

Kecamatan Tumpaan Kabupaten Minahasa Selatan." Jurnal Administrasi

Publik 1, no. 010 (2015).

https://ejournal.unsrat.ac.id/index.php/JAP/article/view/6537.

Miles, Matthew B., A. Michel Huberman, dan Johnny Saladana. Qualitative Data

Analysis A Methods Sourcebook Edition 3. New York: SAGE Publications, 2014.

Panitia FJA 2018. "Buku Panduan Festival Jazirah Arab 2018." HMJ BSA UIN Maulana Malik Ibrahim Malang, 2018.

http://festivaljaziraharab.blogspot.com/p/blog-page_44.html.

Paselle, Enos. "Perencanaan Pembangunan Partisipatif: Studi Tentang Efektivitas Musrenbang Kec. Muara Badak Kab.Kutai Kartanegara." Jurnal Paradigma (JP) 2, no. 1 (2017): 10-25. http://e-

journals.unmul.ac.id/index.php/JParadigma/article/view/339.

Rahmah, Ulfah Fauziyah. "Program Pembelajaran Bahasa Arab Di SMP Plus Al-

Aqsha Jatinagor Sumedang." An Nabighoh: Jurnal Pendidikan Dan 
54 | Al Lastu Nurul Fatim, Ahmad Faizal Amin, Tsabit Nurrahman, Zakiyah Arifa

Pembelajaran Bahasa Arab 21, no. 02 (2019): 255.

https://doi.org/10.32332/an-nabighoh.v21i02.1680.

Razimona, Thia. "Pengawasan dan Evaluasi Program Bahasa Arab untuk

Peningkatan Berkelanjutan di Universitas Islam Negeri Maulana Malik

Ibrahim, Malang." Al-Ma'rifah: Jurnal Budaya, Bahasa, dan Sastra Arab 16,

no. 2 (2019): 1-15.

http://journal.unj.ac.id/unj/index.php/jba/article/view/9471.

Rusman. Model-Model Pembelajaran Mengembangkan Profesionalisme Guru.

Jakarta: Grafindo Persada, 2011.

Sa'ud, Udin Syaefudin, dan Abin Syamsuddin Makmun. Perencanaan Pendidikan:

Suatu Pendekatan Komprehensif. Bandung: Remaja Rosdakarya, 2014.

Shalfiah, Ramandita. "Peran Pemberdayaan Dan Kesejahteraan Keluarga (PKK)

Dalam Mendukung Program-Program Pemerintah Kota Bontang." Jurnal

Fisipol Universitas Mulawarman 1, no. 3 (2017): 975-84.

http://perpustakaan.unmul.ac.id/ejournal/index.php/um/article/view/92.

Siswanto. Pengantar Manajemen. Jakarta: Bumi Aksara, 2010.

Sugiyanto. Dasar-Dasar Manajemen Kristiani. Jakarta: Gunung Mulia, 2008.

Trianto. Mendesain Model Pembelajaran Inovatif-Progresif : Konsep, Landasan dan Implementasinya pada Kurikulum Tingkat Satuan Pendidikan. Jakarta:

Kencana Prenada Media Group, 2010.

Usman, Husaini. Manajemen: Teori, Praktik, Dan Riset Pendidikan. Jakarta: Bumi Aksara, 2008.

Wekke, Ismail Suardi. Model Pembelajaran Bahasa Arab. Yogyakarta: Deepublish

Publisher, 2012. 